\title{
EVALUATING IMPACT OF THE COMMON AGRICULTURAL POLICY 2004-2013 DIRECT PAYMENT SCHEME ON ECONOMIC SUSTAINABILITY OF AGRICULTURE IN LITHUANIA
}

\begin{abstract}
The Common Agricultural Policy (hereinafter - CAP) direct payment scheme has contributed to structural change in Lithuanian agriculture. In particular, it has influenced farmers' behaviour by making them reconsider their participation in agricultural production, leading to farm exits or reorientation towards production of cereal. The problem of the research: in order to assess if Single Area Payment Scheme worked for sustainable development of agriculture in Lithuania, the extent to which the CAP 2004-2013 direct payment scheme has contributed to the increase/reduction of viability and economic attractiveness of different types offarming in Lithuania is examined. The objective of the research is to carry out selection of indicators that characterize the economic attractiveness of different types of farming and to apply these selected indicators for assessing the impact of CAP 2004-2013 direct payment scheme in Lithuania.
\end{abstract}

Key words: CAP, direct payment scheme, economic attractiveness, economic sustainability, indicators.

\section{CAP direct payment scheme: 2003 reform towards sustainability}

The Mid-term review of the Common Agricultural Policy in 2003/2004 has strengthened the multifunctional role of agriculture by implementing "decoupling", "modulation" and "cross-compliance" and created a number of significant changes in agricultural production in all EU Member States (Giannakis and Efstratoglou, 2011). Specifically, the reform shifted emphasis away from commodity support towards sustainable agriculture, environmental contracts, 
diversified production practices and rural development (Lindberg, 2011). Right in time with this reform towards sustainability, new Member States started implementation of CAP (Gay et al., 2005). The decoupling was applied in subsidies and integration through rights in the Single Payment Scheme (SPS) as well as in the Single Area Payment Scheme (SAPS). The latter was a transitional, simplified income support scheme offered to the Member States who joined the EU in 2004 and 2007 (EU-12) as an option in order to facilitate the implementation of direct payments (Markopoulos et al., 2015).

Whole CAP and especially its one of the best-funded measures - direct payment scheme - should have contributed to the objectives of sustainable agriculture (Meléndez-Ortiz et al., 2009). However, ensuring sustainability (universally accepted as three-dimensional - economic, social and environmental - subject) of direct payments is rather complicated and challenging goal. First of all, direct payments were conceived to perform economic function without deepening social conflict and segregation between different farm groups or farming types, while contributing to securing environmentally sustainable farming practice (Ferrer and Kaditi, 2007). The CAP has presupposed that direct payment scheme should have contributed to the maintenance of environmental standards; food safety, animal welfare, competitiveness, market orientation, income stability for farmers (Erjavec and Erjavec, 2009) (see Figure 1).

- maintenance of environmental standards

- food safety

- animal welfare

- income stability for farmers

- competitiveness

- market orientation

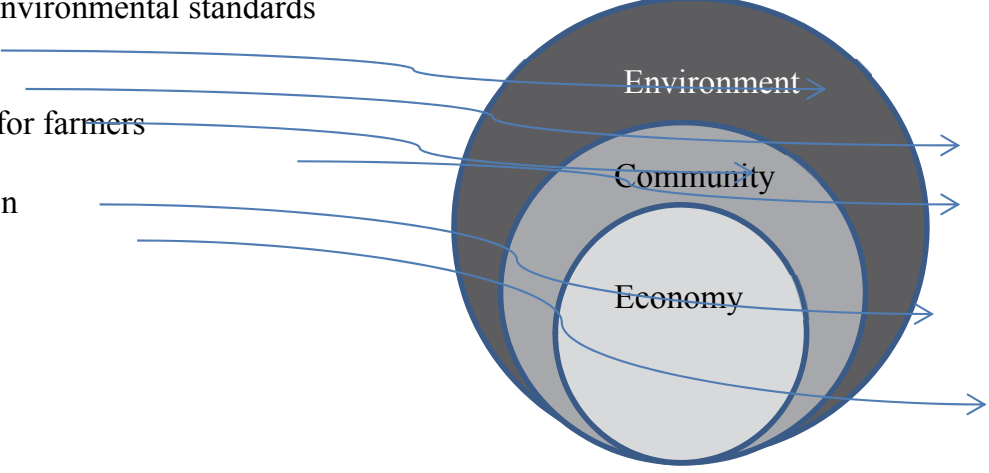

Fig. 1. The direct payment scheme's contribution to the agricultural sustainability. Source: own elaboration according to Erjavec, K., Erjavec, E., 2009, 2015.

However the sustainability role of the direct payment scheme eventually had stronger socio-economical dimensions, such as reduction of income inequality among farmers, reduction of unemployment rate in rural areas, etc. (Schmid et al., 2006). Therefore, while analysing impact of the direct payment scheme on the agricultural sustainability, this paper places a special attention to direct pay- 
ment scheme's economic sustainability, i.e. the most elusive component of the triple bottom line approach. Economic sustainability is integrally linked to the environmental and social outcomes a farm achieves. Although good financial and (in a broader sense) economic performance might mean that farm survives in the short run, it does not necessarily secure a long-term economic future, nor does it guarantee positive environmental or social outcomes. Moreover, this paper looks at the economic sustainability of agriculture in the context of direct payment impact on choice of specialization through economic attractiveness.

\section{Methodology}

In this paper economic sustainability in agriculture is linked with the maintaining of current farming type by farmer while securing sufficient level of income in the long run. Farmers' choice on specialization depends on many indicators; however, it is complicated to specify which of those indicators outline the "economic attractiveness' best. According to Knoke et al. (2001) and Georgopoulou et al. (2008), the economic attractiveness of farming activities is closely linked to economic performance: if it is cost-effective, then it is economically attractive too. Thus, economic attractiveness and efficiency is closely linked. In the Lithuanian literature, there are a number of 'economic efficiency' interpretations that are applicable to the economic activities assessment (see Table 1).

The analysis of various definitions of 'efficiency' led to general concept that efficiency is seen as a ratio between company's performance and the resources consumed to achieve those performance results.

Economic efficiency - i.e. better performance (higher profits) at lower costs - was primarily analysed in order to establish a model for assessing economic attractiveness of farmers' choice in specialisation. Andrijauskienè (2004) argues that the term 'economic efficiency' means effectiveness of production activities, i.e. shows the relationship between economic activities (process) and the objectified performance (results).

One of the main financial indicators that characterise economic efficiency is profitability. Berry ratio is commonly applied indicator (Przysuski and Lalapet, 2005); it shows the company/farm profitability resulting from their typical value-building functions, assuming that the costs incurred in the execution of these functions are included in the operating costs (Berry, 1999). Berry ratio may be applied only with existence of a strong correlation between company/ farm operating costs and sales revenue.

Another widely applied economic efficiency indicator is Gross profit per employee (or one annual work unit, AWU) (Berger et al., 1993; Chavas et al., 1993). This ratio shows how efficiently the company or farm use human resources. Dividends are also in some cases taken into consideration in line with this indicator in order to assess cash balance at the end of fiscal year (Porter and Scully, 1987). 
Table 1

Definitions of the economic efficiency

\begin{tabular}{|c|c|}
\hline Authors & Definition of term \\
\hline Mackevičius and Daujotaitè 2011 & Ratio of created products and used resources. \\
\hline Buklytė and Ruževičius 2010 & $\begin{array}{l}\text { Comprehensive tool for assessing the company's operational } \\
\text { excellence and its inner potential }<\ldots>\text { with regard to } \\
\text { performance of the activities, customers, people and society. }\end{array}$ \\
\hline Štaras and Šiopè 2010 & Ratio of costs, resources and qualitative output. \\
\hline Daft 2009 & Amount of resources used to achieve organizational goals. \\
\hline Deksnienè et al. 2007 & $\begin{array}{l}\text { Level of utilization of productive resources, guaranteeing } \\
\text { maximum effect. }\end{array}$ \\
\hline Šimaitytė et al. 2006 & $\begin{array}{l}\text { Company's operating efficiency, effectiveness, expressed } \\
\text { in the ratio of the achieved results and the costs used. }\end{array}$ \\
\hline Puškorius 2002 & $\begin{array}{l}\text { Ratio of operating results to complex resources, deposits, } \\
\text { costs and other. }\end{array}$ \\
\hline
\end{tabular}

Source: own elaboration.

It is important to draw attention to the achievement of maximum output with the existing resources and technology, working in a moderate pace, avoiding unnecessary wastage and defects. ROCE (Return on Capital Employed) is another indicator widely used for economic effectiveness analysis (Muhammad 2009; Whiting 1986; Andersson 2006). ROCE is calculated as ratio of company's operating profit to the capital employed (Whiting, 1986). The indicator demonstrates return on capital investments in the core business activities. It is often used in the financial reports intended for investors and company owners (Whiting, 1986).

One of the recently emerged indicators describing economic efficiency of technologies is investment depreciation rate. This indicator is especially important while establishing a new company or while changing/expanding its activities, as it helps to determine how long the capital investments will generate profit.

Labour productivity is essentially important factor in economic efficiency of business (Arrow et al., 1961; Harris et al., 2005), no matter if it is labour-intensive or not. However, in evaluating attractiveness, it can be noticed that the less labour-intensive own business is, the more attractive it is (Saez, 2000), especially in family farm case, when the basic work is performed by family work units.

Initial overview of available economic efficiency measurement tools led to development of a system of indicators (see Figure 2) for assessment of company's economic attractiveness or, in case of farm, choice to specialize in a certain farming type.

The economic efficiency indicators mainly used for companies, were adapted to be applicable for farms. Basing on 2004-2013 data of respondent farms belonging to Farm Accountancy Data Network (hereinafter FADN), two indicator systems - Alfa and Status Quo - were formed with six indicators (Berry ratio, 
Family farm income per 1 FWU, Savings at the end of the year, Labour input (hours), Rate of return and Investment depreciation rate). In Alfa indicator system, all the above listed indicators are calculated eliminating all direct financial support available to farmers (i.e. direct payments, organic farming (OF) payments, and less favoured areas (LFA) payments). Meanwhile in Status Quo indicator system, values of the same indicators were calculated basing on results of factual implementation of 2004-2013 CAP direct payment scheme in Lithuania. Indicator values for a ten year period (from 2004 to 2013) are estimated separately for each of the selected farming type. In this model, a shortened set of FADN farming types (eliminating mixed types) is applied, containing the following - Specialist cereal/rapes ${ }^{1}$, General field cropping ${ }^{2}$, Horticulture ${ }^{3}$, Specialist dairying ${ }^{4}$, Grazing livestock ${ }^{5}$ (see Figure 3).
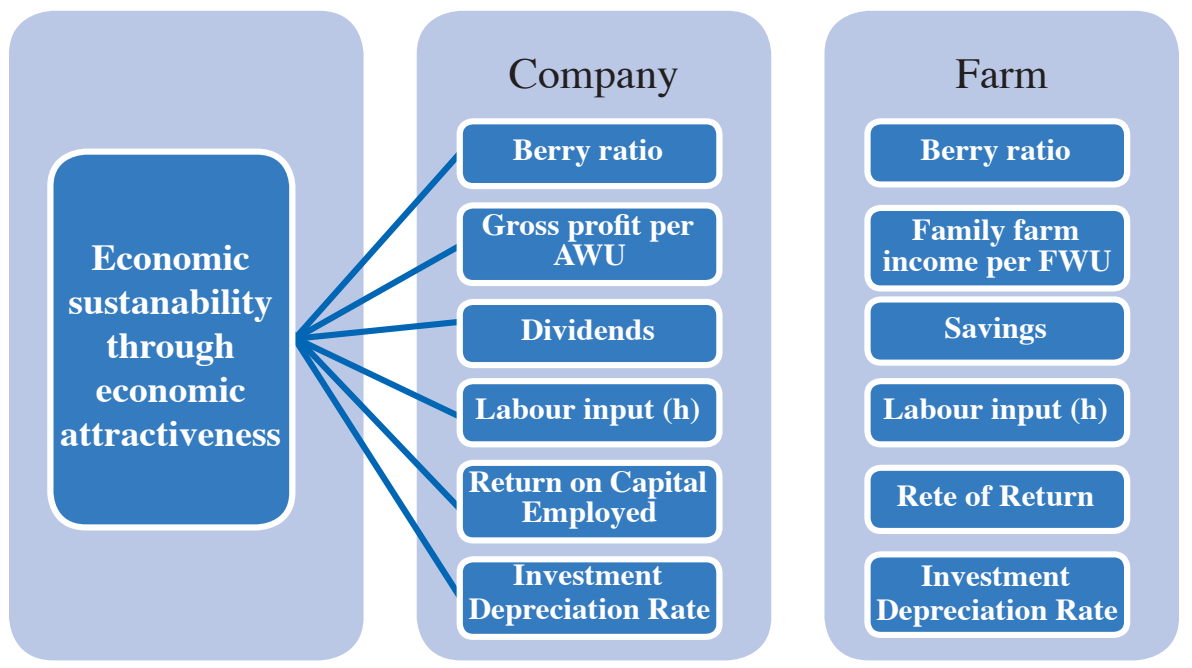

Fig. 2. System of indicators to measure economic attractiveness of farming specialisation.

Source: own elaboration.

\footnotetext{
${ }^{1}$ Specialist cereal/rapes farm type according to FADN, when cereals, oilseeds and protein crops make more than $2 / 3$ of total farm production.

${ }^{2}$ General field cropping farm type according to FADN, when production of any type of crop makes more than $2 / 3$ of total farm production, but cereals, oilseeds and protein crops make not more than $2 / 3$ in the total production.

${ }^{3}$ Horticulture farm type according to FADN, when horticulture makes more than $2 / 3$ of total farm production.

${ }^{4}$ Specialist dairying farm type according to FADN, when production from dairy cows makes more than $3 / 4$ of the farm's total grazing livestock production, and production from the grazing livestock makes more than 1/10 of farm's total grazing livestock and fodder crop production.

${ }^{5}$ Grazing livestock farm type according to FADN, when total livestock production makes more than $2 / 3$ of grazing livestock.
} 


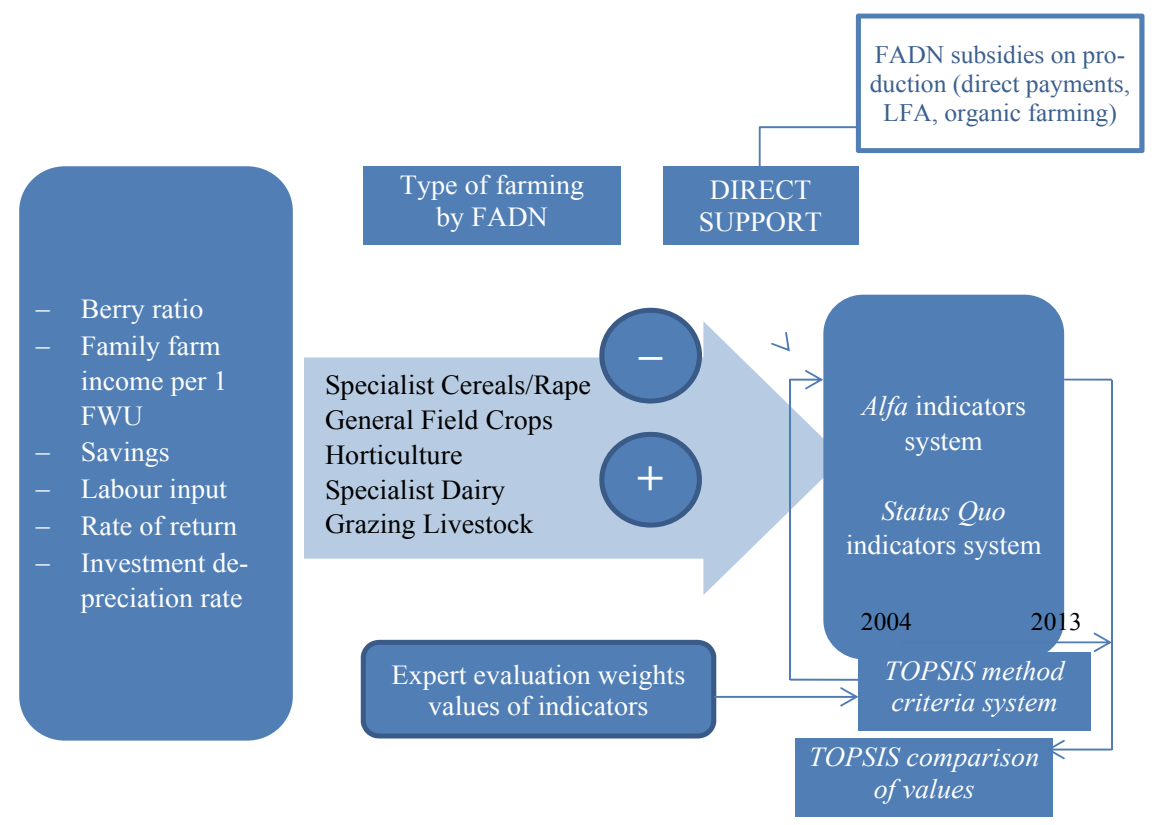

Fig. 3. Model of economic attractiveness of farmers' choice in specialisation.

Source: own elaboration.

In the Alfa system, Berry ratio was calculated by dividing farm's gross profit (without subsidies ${ }^{6}$ and depreciation) by total production costs (variable and fixed). In the Status Quo system, the same formula was applied for calculating Berry ratio except that production subsidies were added to farm's gross profit.

Gross profit was calculated by deducting total production costs, variable and fixed (including VAT payable), from total farm output. In the Status Quo system subsidies for production were added to gross profit. Gross profit per 1 annual farm working unit ( $€ / A W U)$ was calculated by dividing gross profit by number of AWU.

In the Alfa system, savings at the end of the year $(€)$ were estimated in the following way: cash flow without subsidies plus asset sales-purchase balance plus quota sales-purchase balance minus returned debts minus private expenditures. In the Status Quo system, savings at the end of the year adds production subsidies received.

Farm labour input includes working time (hours) of farmers, their spouses and other farm members as well as hired employees. The value of this indicator is identical in both: Alfa and Status Quo systems.

\footnotetext{
${ }^{6}$ Subsidies = production subsidies + investment support; where production subsidies contain direct payments, less favoured areas (LFA) payments, organic farming (OF) payments, support in case of disaster, and other production-related subsidies.
} 
In the Alfa system, Rate of return (\%) was estimated by dividing net profit ${ }^{7}$ (without subsidies and depreciation) by total value of agricultural assets, including rented land, at the beginning of year. In the Status Quo system, net profit adds production subsidies.

In both: Alfa and Status Quo systems, Investment depreciation had the same value (\%), which has been estimated by dividing net investments by gross investments ${ }^{8}$.

Ten Alfa indicator systems were composed basing on the estimated indicator values from the years between 2004 and 2013. Equally, ten Status Quo indicator systems were drawn.

According to Podvezko (2010) the TOPSIS method is the most suitable in evaluation of described model. Thus, each of the system had TOPSIS method applied on them. The calculated TOPSIS values demonstrate dynamics of economic attractiveness of each farming specialisation over the selected years. Striving to identify the most economically attractive farming specialisation over the whole year range, a mathematical average of values of normalized TOPSIS criteria was drawn: $\mathrm{C}_{\mathrm{jt}}^{*}: \overline{C_{j t}^{*}}=\frac{1}{k} \sum_{t=1}^{k} C_{j t}^{*}(k=1, \ldots, 10$, where $k=1$ corresponds to year 2004, $k=2$ respectively corresponds to year $2005, \ldots, k=10$ corresponds to year 2013).

\section{Outcomes}

According to the results, retrieved from the Alfa indicator system analysis, while direct aid to farms is eliminated, sole cultivation of Specialist cereals/ rapes in 2012 would have been the most attractive farming specialisation in Lithuania, in comparison to other farm types. In any other year, the most economically attractive farming activity would have been horticulture (see Table 2).

Economic attractiveness of dairy farming may be observed in 2005 and 2006, while between 2008 and 2010 general field cropping might have been considered an attractive option too.

Table 3 demonstrates the major outcome of assessing economic attractiveness of different farming specialisation according to the developed indicator systems, i.e. 2004-2013 Alfa and Status Quo systems' average C C jt $^{*}$ TOPSIS values.

In the Alfa indicator system case (when direct aid to farmers is eliminated), the average of indicators values demonstrated a strong economic attractiveness of solely horticultural farming over the 2004-2013 period. The other farming types were less attractive by at least $42 \%$ in comparison to horticulture. The second most economically attractive type of farming was general field cropping; the third was dairying (half as economically attractive as horticultural farm-

\footnotetext{
${ }^{7}$ Net profit $=$ Gross profit minus family remuneration.

${ }^{8}$ Gross investments equals' difference between purchase and sales price of land, forest, permanent crops, farm buildings, machinery and quotas. Gross investments - depreciation $=$ net investments.
} 
ing). Cultivation of cereals/rapes without direct payments would have been only fourth option for farmers, while grazing livestock sector would have been the least attractive.

Table 2

Normalized values of Alfa indicator system in 2004-2013

\begin{tabular}{ccccccc}
\hline $\mathrm{C}_{\mathrm{jt}}^{*}$ & \multicolumn{5}{c}{ Farm types } \\
\hline Years & $\begin{array}{c}\text { Specialist } \\
\text { Cereals/Rapes }\end{array}$ & $\begin{array}{c}\text { General Field } \\
\text { Cropping }\end{array}$ & Horticulture & Dairying & $\begin{array}{c}\text { Grazing } \\
\text { livestock }\end{array}$ & $\sum_{j=1}^{5} C_{j t}^{*}$ \\
\hline 2004 & 0.126 & 0.194 & 0.454 & 0.128 & 0.097 & 1 \\
2005 & 0.084 & 0.190 & 0.370 & 0.233 & 0.123 & 1 \\
2006 & 0.038 & 0.124 & 0.421 & 0.247 & 0.170 & 1 \\
2007 & 0.192 & 0.157 & 0.401 & 0.179 & 0.071 & 1 \\
2008 & 0.169 & 0.262 & 0.312 & 0.156 & 0.102 & 1 \\
2009 & 0.061 & 0.225 & 0.379 & 0.201 & 0.134 & 1 \\
2010 & 0.152 & 0.242 & 0.323 & 0.175 & 0.108 & 1 \\
2011 & 0.195 & 0.204 & 0.335 & 0.177 & 0.089 & 1 \\
2012 & 0.333 & 0.216 & 0.298 & 0.103 & 0.052 & 1 \\
2013 & 0.146 & 0.246 & 0.291 & 0.199 & 0.119 & 1
\end{tabular}

Source: own elaboration.

Table 3

2004-2013 Alfa system indicators and Status Quo system indicators 2004-2013 average TOPSIS values

\begin{tabular}{lccccc}
\hline \multicolumn{1}{c}{$\overline{C_{J t}^{*}}$} & \multicolumn{5}{c}{ Farm types } \\
\hline \multicolumn{1}{c}{$\begin{array}{c}\text { Indicator } \\
\text { systems }\end{array}$} & $\begin{array}{c}\text { Specialist } \\
\text { Cereals/Rapes }\end{array}$ & $\begin{array}{c}\text { General Field } \\
\text { Cropping }\end{array}$ & Horticulture & $\begin{array}{c}\text { Specialist } \\
\text { Dairying }\end{array}$ & $\begin{array}{c}\text { Grazing } \\
\text { livestock }\end{array}$ \\
\hline Alfa & 0.150 & 0.206 & 0.358 & 0.180 & 0.107 \\
Status Quo & 0.288 & 0.225 & 0.219 & 0.151 & 0.116 \\
$\begin{array}{l}\text { Variation } \\
\begin{array}{l}\text { Status Quo } \\
\text { to Alfa) }\end{array}\end{array}$ & $+93 \%$ & $+9 \%$ & $-39 \%$ & $-16 \%$ & $+9 \%$ \\
\hline
\end{tabular}

Source: own elaboration.

Direct support scheme under the CAP 2004-2013 in Lithuania (as seen in Status Quo system case) had fundamentally changed the economic attractiveness of farming specializations (Figure 4). 


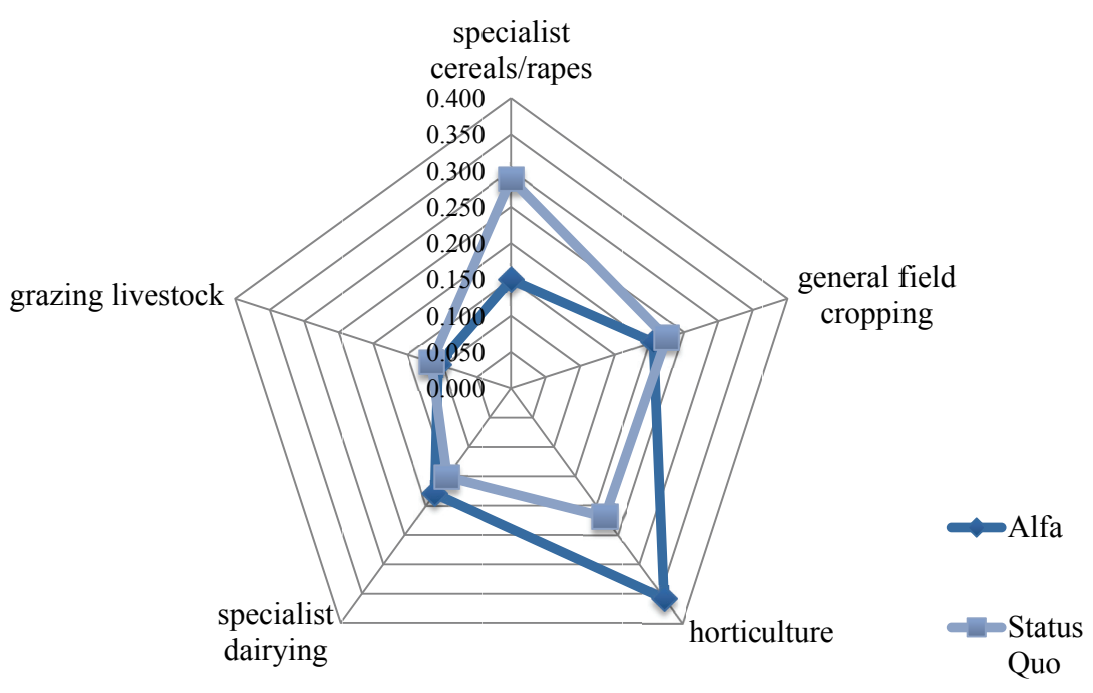

Fig. 4. Comparison of 2004-2013 average TOPSIS values in Alfa and Status Quo indicator systems.

Source: own elaboration.

The obtained TOPSIS method values clearly demonstrate that the direct support scheme has made cultivation of specialist cereals and rapes the most economically attractive agricultural specialization for Lithuania farmers in 2004-2013 period. Compared to Alfa scenario, which eliminates effects of the direct support, the economic attractiveness of Specialist cereals/rapes cultivation has increased by 93\%. According to Statistics Lithuania (Statistics, 2014), cereal crop area has increased by more than 27\% from 2005 to 2013; and in 2013 it already accounted for about $45 \%$ of all utilized agricultural area (UAA) in Lithuania.

According to TOPSIS results, in Status Quo system case, the second most popular farming activity General field cropping remained at similar level as in the Alfa system. The economic attractiveness of this farming type has increased by $9 \%$ as compared to 2004 .

Meanwhile attractiveness of horticulture was significantly $(-39 \%)$ reduced by direct support scheme applied in Lithuania in 2004-2013: according to Statistics Lithuania (2015), fruit and vegetable production area decreased by $36.3 \%$ and $23.4 \%$, respectively, during the same period.

Impact of direct payment scheme on Specialist dairying sector was negative as well: its economic attractiveness decreased by $16 \%$. In Status Quo system Specialist dairying farming type has $48 \%$ lower economic attractiveness than specialist cereals/rapes. Grazing livestock has become slightly more attractive 
$(+9 \%)$ to farmers due to the subsidies from direct payment scheme. Nevertheless this farming type is still $60 \%$ less economically attractive than Specialist cereals/rapes.

\section{Conclusions}

Since 2003, direct payment scheme, as one of the most intensely financed CAP measures, together with whole CAP in general, was expected to contribute to the objectives of sustainable agriculture. However, the role of the direct payment scheme focused on stronger socio-economical dimensions of agricultural sustainability, such as reduction of income inequality among farmers, reduction of unemployment rate in rural areas, etc.

Identification of the link between economical sustainability, economical attractiveness and economic efficiency allowed development of a model for assessing impact of direct payment scheme on economic sustainability.

The values obtained within application of TOPSIS method, showed that direct support scheme made cultivation of specialist cereals and rapes the most economically attractive agricultural specialization for Lithuanian farmers in 20042013. The economic attractiveness of this particular farming type has increased by $93 \%$ as compared to Alfa system scenario, where the effects of production subsidies were eliminated.

Model of economic attractiveness to different farming types essentially replicates structural changes in Lithuanian agriculture in 2004-2013.

According to the outcomes brought by applying this pilot economic attractiveness evaluation model, the 2004-2013 CAP direct support in Lithuania basically prompted economic attractiveness of such farming type as Specialist cereal/rape that in turn stimulated farmers' reorientation towards this most economically attractive type of farming.

In case of Lithuania, SAPS has become economically attractive niche for farmers' strong orientation towards financial support and basically repositioning the major part of economic risks on direct payments. As proved by Alpha system case results, without the production support, cereals/rape sector would have been way less economically attractive and in terms of agricultural sustainability can be more sustainable. 


\section{Literature:}

Andersson, T., Haslam, C., Lee, E. (2006). Financialized accounts: Restructuring and return on capital employed in the S\&P 500. In: Accounting Forum, vol. 30, no. 1, pp. 21-41. Elsevier.

Andrijauskienè, A. (2004). İmonių ekonomika. Vilnius: Presvika, pp. 113-114.

Arrow, K.J., Chenery, H.B., Minhas, B.S., Solow, R.M. (1961). Capital-labor substitution and economic efficiency. The Review of Economics and Statistics, pp. 225-250.

Berger, A.N., Hancock, D., Humphrey, D.B. (1993). Bank efficiency derived from the profit function. Journal of Banking \& Finance, 17(2), pp. 317-347.

Berry, C. (1999). Berry Ratios: Their Use and Misuse. Global transfer pricing.

Buklytė S., Ruzevičius J. (2010). Total quality management impact on Lithuanian companies' performance efficiency // Organizaciju vadyba: sisteminiai tyrimai. Vilnius: Vilniaus universitetas, pp. 55-70.

Chavas, J.P., Aliber, M. (1993). An analysis of economic efficiency in agriculture: a nonparametric approach. Journal of Agricultural and Resource Economics, pp. 1-16.

Daft, R.L. (2009). Organization theory and design. 10 ${ }^{\text {th }}$ ed. - Mason: South - Western Cengage Learning, pp. 20.

Deksnienè, J. et al. (2007). Lietuvos tekstilès įmonių ūkinès veiklos efektyvumo ịvertinimas ir tendencijos. Ekonomika ir vadyba: aktualijos ir perspektyvos. Šiauliai: VŠI Šiauliu universiteto leidykla, no. 2(9), pp. 37-44.

Erjavec, K., Erjavec, E. (2009). Changing EU agricultural policy discourses? The discourse analysis of Commissioner's speeches 2000-2007. Food Policy, 34(2), pp. 218-226.

Ferrer, J.N., Kaditi, E.A. (2007). The EU added value of agricultural expenditure-from market to multifunctionality-gathering criticism and success stories of the CAP. European Parliament, Policy Department on Budgetary Affairs, Brussels, Belgium.

Gay, S.H., Osterburg, B., Baldock, D., Zdanowicz, A. (2005). Recent evolution of the EU Common Agricultural Policy (CAP): state of play and environmental potential. MEACAP WP6, D4b, Federal Agricultural Research Centre, Braunschweig and Institute for European Environmental Policy, London.

Georgopoulou, E., Hontou, V., Gakis, N., Sarafidis, Y., Mirasgedis, S., Lalas, D.P., Triantafilopoulos, T. (2008). BEAsT: a decision-support tool for assessing the environmental benefits and the economic attractiveness of best available techniques in industry. Journal of Cleaner Production, 16(3), pp. 359-373.

Giannakis, E., Efstratoglou, S. (2011). An input-output approach in assessing the CAP reform impact of extensive versus intensive farming systems on rural development: The case of Greece. Agricultural Economics Review, 12(1), pp. 81-90.

Harris, R., Siegel, D.S., Wright, M. (2005). Assessing the impact of management buyouts on economic efficiency: Plant-level evidence from the United Kingdom. Review of Economics and Statistics, 87(1), pp. 148-153.

Knoke, T., Moog, M., Plusczyk, N. (2001). On the effect of volatile stumpage prices on the economic attractiveness of a silvicultural transformation strategy. Forest policy and economics, 2(3), pp. 229-240.

Lindberg, G. (2011). Linkages: economic analysis of agriculture in the wider economy. Vol. 2011, no. 6. 
Mackevičius, J., Daujotaitè, D. (2011). Veiklos audito elementai: analizè ir auditas. Socialiniu mokslu studijos. No. 3(2), pp. 459-472.

Markopoulos, T., Karelakis, C., Galanopoulos, K., Mattas, K. (2015). Did The 2004 Cap Reform Affect Production Practices of Cereals? Insights From The Agricultural Input Suppliers. Scientific Bulletin-Economic Sciences, 14(2), pp. 71-83.

Meléndez-Ortiz, R., Bellmann, C., Hepburn, J. (eds.). (2009). Agricultural subsidies in the WTO green box: ensuring coherence with sustainable development goals. Cambridge University Press.

Muhammad, N.M.N., Ismail, M.K.A. (2009). Intellectual capital efficiency and firm's performance: Study on Malaysian financial sectors. International Journal of Economics and Finance, 1(2), pp. 206.

Podvezko, V., Podviezko, A. (2010). Dependence of multi-criteria evaluation result on choice of preference functions and their parameters, Technological and Economic Development of Economy no. 16(1), pp. 143-158.

Porter, P.K., Scully, G.W. (1987). Economic efficiency in cooperatives. Journal of law and economics, pp. 489-512.

Przysuski, M., Lalapet, S. (2005). A Comprehensive Look at the Berry RatioIn Transfer Pricing. Tax Notes Int'l, November 21, 2005, pp. 759.

Puškorius, S. (2002). 3E koncepcijos plètra. Viešoji politika ir administravimas, no. 3, pp. 31-38.

Saez, E. (2000). Optimal income transfer programs: intensive versus extensive labor supply responses (No. w7708). National Bureau of Economic Research.

Schmid, E., Sinabell, F., Hofreither, M.F. (2006). Direct payments of the CAP-distribution across farm holdings in the EU and effects on farm household incomes in Austria. Univ. für Bodenkultur Wien, Department für Wirtschafts-und Sozialwiss., Inst. für Nachhaltige Wirtschaftsentwicklung.

Šimaitytė, D., et al. (2006). AB Linas veiklos ekonominio efektyvumo ịvertinimas. Jaunuju mokslininkų darbai. Šiauliai: VŠI Šiaulių universiteto leidykla, no. 2(9), pp. 13-17.

Štaras, K., Šiopè, A. (2010). VŠİ Centro poliklinikos veiklos efektyvumo vertinimas. Socialiniu mokslu studijos, no. 3(7), pp. 163-176.

Whiting, E. (1986). Return on capital employed. In: A Guide to Business Performance Measurements, pp. 214-231. Palgrave Macmillan UK. 
ARTIOM VOLKOV

JOLANTA DROŽDZ

Litewski Instytut Ekonomiki Rolnictwa

Wilno

\title{
OCENA WPŁYWU PROGRAMU PŁATNOŚCI BEZPOŚREDNICH WSPÓLNEJ POLITYKI ROLNEJ 2004-2013 NA STABILNOŚĆ GOSPODARCZĄ ROLNICTWA NA LITWIE
}

\begin{abstract}
Abstrakt
System płatności bezpośrednich Wspólnej Polityki Rolnej (zwanej dalej WPR) przyczynit sie do zmiany strukturalnej $w$ litewskim rolnictwie. Wszczególności wpłynąt na zachowanie rolników, skłaniajac ich do ponownego rozważenia udziału w produkcji rolnej, co z kolei prowadziło do rezygnacji z prowadzenia gospodarstwa lub zmiany orientacji produkcji na produkcję zbóz. W ramach pracy zbadano $w$ jakim stopniu system płatności bezpośrednich WPR 2004-2013 przyczynił się do podniesienial obniżenia rentowności i atrakcyjności gospodarczej różnych typów rolniczych na Litwie, aby ocenić, czy system jednolitej płatności obszarowej miat wpływ na zrównoważony rozwój rolnictwa na Litwie. Celem badania byt dobór wskaźników charakteryzujących atrakcyjność gospodarcza różnych typów rolniczych oraz zastosowanie tych wybranych wskaźników do oceny wpływu system płatności bezpośrednich WPR 2004-2013 na Litwie.
\end{abstract}

Słowa kluczowe: WPR, system płatności bezpośrednich, atrakcyjność gospodarcza, stabilność gospodarcza, wskaźniki.

Zaakceptowano do druku - Accepted for print: 12.09.2016.

0 ile nie jest to stwierdzone inaczej, wszystkie materiały na stronie są dostępne na licencji Creative Commons Uznanie Autorstwa 3.0 Polska. Pewne prawa zastrzeżone na rzecz Instytutu Ekonomiki Rolnictwa i Gospodarki Żywnościowej - PIB.

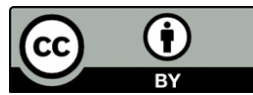

